\title{
ACCUSTOMING STUDENTS' POLITE LANGUAGE THROUGH MOTHER: ITS BARRIERS
}

\author{
${ }^{a}$ Afiifah Al Rosyiidah, ${ }^{b}$ Darul Hikmah \\ ${ }^{a, b}$ Universitas Trunojoyo Madura \\ e-mail: afifah.rosyidah@gmail.com
}

\begin{abstract}
This article principally discusses one of the enticing issues which is to accustom language politeness. This study focuses on the use of MOTHER (Madurese Theme Role Play) to accustom students' language politeness at university level particularly at University of Trunojoyo Madura. It aims to discover and explain how maxim of GSP (General Strategy of Politeness) are utilized in the Madurese Theme Role Play. Moreover, it also aims to reveal some barriers in utilizing MOTHER to accustom students' language politeness.

This study uses qualitative design of the research. In order to get the data, observation and depth interview are applied. In addition, field-notes are used during the observation and interview to collect the data. Besides, audio-recording is also conducted to gain additional detailed information that is likely missing on the fieldnotes. Interactive model of data analysis is applied to analyze the data, including data reduction, data display, and data verification. The result of the study shows that ten maxims of politeness in the implementation of Madurese Theme Role Play are found. The eighty-three data are classified into ten maxims of politeness: generosity maxim, tact maxim, approbation maxim, modesty maxim, obligation (of $\mathrm{S}$ to $\mathrm{O}$ ) maxim, Obligation (of $\mathrm{O}$ to $\mathrm{S}$ ) maxim, agreement maxim, opinion reticence maxim, sympathy maxim, and feeling reticence maxim. Besides, the seven barriers are encountered during the implementation of MOTHER to accustom students' language politeness, including students' difficulties to coordinate and cooperate with the team, to elaborate the plot of the role play, to discover references and find attractive story ideas deal with Madurese themes, to create polite dialogues of the role play, to specifies the context (to whom) the dialogue is addressed to, and to determine the title of role play.
\end{abstract}

Keywords: language politeness, Madurese theme role play 


\section{INTRODUCTION}

In our society, communication is not simply to convey the intentions to interlocutors. People are expected to recognize and apply language ethics or language procedures that fulfill cultural values implemented in our society. The speaker who are able to speak politely will be more admissible in our society rather than those who speak harshly. Furthermore, to communicate ethically can keep people away from social conflicts and avoid conflicts caused by socially inappropriate language in the communication. This is something that must be considered by the speakers.

Communicating in polite language is an obvious form of good language procedures. All language users are required to speak politely. In other hand, what we think about polite language is still hazy because being linguistically polite for people in one culture does not mean being polite for people in another culture. Language politeness is truly related to the culture of the language itself, yet "the values considered norms vary from culture to culture" (Leech, 2014). In this case, Watts (2003) pointed out that polite language might be characterized as an expression, namely language, which displays respect towards or consideration for others. It means that to be considered linguistically polite in communication, the speaker might need to avoid using too direct language. For example, in some culture there is a need to apply language containing respectful forms of address, such as "sir" or "madam" and language displaying certain polite formulaic utterance, such as "please", "thank you", "excuse me" or "sorry" in order to be considered polite in communicative interaction.

The term 'language politeness' is commonly discussed in the area of Pragmatics. It is related to the way how the speakers show an honor for others" "face" (i.e. public self-image) in conversation (Brown and Levinson, 1987); reinforce interpersonal relationships; and follow the rules for appropriate behaviors considered by the society (Leech, 2014). Public self-image (self-esteem (Leech, 2014)), in this case, includes the feeling and desires ('face-wants'(Kadar and Haugh, 2013)) of the interlocutors. Following Brown and Levinson (1987), in the case of strategy of showing politeness to interlocutors Leech (2014) mentioned "positive face goal" which deals with the need of avoiding loss of face and "negative face goal" which deals with the need of enhancing face. Avoiding loss of face means that speakers need to lessen potency of lowering interlocutors' self-esteem in communication. On the other hand, enhancing face means that speakers need to heighten the hearers' self-esteem.

A phenomenon related to the issue of language politeness-which is occasionally termed 'linguistic politeness' (Watts, 2003) — often occurs in our daily interaction. The phenomenon is found both in direct (face-to-face) communication and indirect communication like in communication through online application media. The following excerpt taken from personal chat in Whatsapp is as an example.

\section{S: "Mam, mau tanya, besok berarti kita ga ada pertemuan ya?"}

(Mom, just for asking, we won't have class tomorrow, right?)

T: "???" (only replies with some question marks)

The example above is taken from personal Whattsapp chat between a lecturer and her student of a state university in Madura. Considering the running value of norms in Madurese society, the way the student communicates to the lecturer is perceived 'impolite' because the expression used is too direct and structurally informal, that lowers the self-esteem of the lecturer. What is socially expected in this situation is that the student uses indirect expressions; lessens the directness; which can maintain or 
heighten the teacher's self-esteem. In simpler words, the student is expected to apply what Leech (2014) called "Neg-Politeness" strategy.

It is expected that the student can enhance the lecturer's face (to maintain her self-esteem) using expression which is not too direct, such as by adding polite formulaic utterance like "mohon maaf" (excuse me), "mohon ijin" (please allow...), and using formal structure of the language in questioning. In relation to such situation, viewed from the social norms running in Madura, the social relation between $t$ and student is what Leech (2014) called 'vertical social distance'. In this case, the student is on scale of lower status and power while the teacher is on scale of higher status and power.

The example above is one of examples of socially inappropriate language used by students at university level. It is felt as a crucial issue which urgently needs solving. Moreover, it is becoming lecturer's issue to overcome. As an educator, the lecturer has moral responsibilities to solve the problem by educating the students to be good language users in their communication. It is a duty for the lecturer to teach and accustom the students to use socially acceptable and appropriate language in their communicative interaction because "politeness is not something we are born with, but something we have to learn and be socialized into" (Watts, 2003).

In teaching and accustoming politeness to the students of University of Trunojoyo Madura, we need interesting and creative activities so that it is always remembered and applied in their daily lives. One of the interesting and creative ways is a method called MOTHER. It stands for Madurese Theme Role Play. MOTHER is a roleplaying method using themes about Madurese culture as local wisdom. The use of themes related to Madurese culture will certainly provide added value. The students who come from various regions in Indonesia are able toc understand and appreciate the culture in which they live during they study at University of Trunojoyo Madura.

Roleplaying method is chosen because it has several benefits. One of them is to help students to understand themselves in everyday life, so that they are able to explore feelings and develop sympathy and empathy in everyday life. This benefit closely related to how to respect other people from various social classes with polite and appropriate language.

Based on the descriptions above, this article tries to discuss how the maxims of General Strategy of Politeness are applied in MOTHER (Madurese Theme Role Play). Also, this article is in attempt to reveal some barriers in utilizing MOTHER to accustom students' polite language.

\section{THEORETICAL FRAMEWORK}

In analyzing data related to language politeness, pragmalinguistic and sociopragmatic approaches are applied. Pragmalinguistic politeness scale and sociopragmatic politeness scale are used to view language politeness (Leech, 2014). Degrees of politeness especially the lexigrammatical form and semantic interpretation of the utterance used by the participants in communication can be measured by pragmalinguistic scale. Meanwhile, degrees of politeness in relation to norms in a given society, group, or situation of the communication can be understood by sociopragmatic scale. So, different from the former scale, the latter scale can show "over-politeness" and "under-politeness," as well as "politeness appropriate to the situation." In analyzing the data and interpreting the finding, this study utilizes pragmalinguistic approach that is combined with sociopragmatic approach. 
Leech (2014) stated that in communicating with other people, a speaker should express utterances containing the favorable value of the interlocutor and avoid offenses. For this case, a model of politeness strategy called GSP (General Strategy of Politeness) with 10 component maxims is exemplified. The ten maxims include: 'Generosity'; 'Tact'; 'Approbation'; 'Modesty'; 'Obligation' (of S to O); 'Obligation' (of O to S); 'Agreement'; 'Opinion reticence'; 'Sympathy'; and 'Feeling reticence'.

\section{METHODS}

This study utilizes qualitative design of the research to explain the students' language politeness phenomenon happening at Universitas Trunojoyo Madura. In order to get the data, observation and depth interview are used. In addition, field-notes are used during the observation and interview to collect the data. Moreover, audiorecording is also done to get additional detailed information that is likely missing on the field-notes. In analyzing the data, interactive model of data analysis is applied. They are data reduction, data display, and data verification.

\section{RESULTS AND DISCUSSION}

Some utterances containing maxims of GSP (General Strategy of Politeness) are found in two scripts of Madurese Theme Role Play entitled "Marlena" and "Jumpa Kawan", and eighty-three data which are classified on the basis of GSP have been found. A table is used to display the data. The data are classified into General Strategy of Politeness, including: generosity maxim, tact maxim, approbation maxim, modesty maxim, obligation (of $\mathrm{S}$ to $\mathrm{O}$ ) maxim, Obligation (of $\mathrm{O}$ to $\mathrm{S}$ ) maxim, agreement maxim, opinion reticence maxim, sympathy maxim, and feeling reticence maxim proposed by Leech (2014). They are shown in Table 1.

Table 1. General Strategy of Politeness Found in MOTHER

\begin{tabular}{|l|l|l|l|l|l|l|l|l|l|l|}
\hline \multirow{2}{*}{$\begin{array}{c}\text { The title of } \\
\begin{array}{c}\text { Madurese } \\
\text { culture role } \\
\text { play script }\end{array}\end{array}$} & \multicolumn{10}{|c|}{ General Strategy of Politeness (Leech, 2014) } \\
\cline { 2 - 7 } & $\mathbf{M 2}$ & $\mathbf{M 3}$ & $\mathbf{M 4}$ & $\mathbf{M 5}$ & $\mathbf{M 6}$ & $\mathbf{M 7}$ & $\mathbf{M 8}$ & $\mathbf{M 9}$ & M10 \\
\hline MARLENA & 14 & 3 & 5 & 2 & 2 & 0 & 10 & 6 & 2 & 3 \\
\hline $\begin{array}{l}\text { JUMPA } \\
\text { KAWAN }\end{array}$ & 8 & 3 & 5 & 0 & 4 & 3 & 10 & 0 & 3 & 0 \\
\hline Frequency & $\mathbf{2 2}$ & $\mathbf{6}$ & $\mathbf{1 0}$ & $\mathbf{2}$ & $\mathbf{6}$ & $\mathbf{3}$ & $\mathbf{2 0}$ & $\mathbf{6}$ & $\mathbf{5}$ & $\mathbf{3}$ \\
\hline
\end{tabular}

M1: generosity maxim

M2: tact maxim

M3: approbation maxim

M4: modesty maxim

M5: obligation (of $\mathrm{S}$ to $\mathrm{O}$ ) maxim

M6: obligation (of $\mathrm{O}$ to $\mathrm{S}$ ) maxim

M7: Agreement maxim

M8: opinion reticence maxim

M9: sympathy maxim

M10: Feeling reticence maxim 
The table above shows that all GSP are available for the data found in the scripts of Madurese culture role play. Based on the frequency of each maxim, it can be known that all maxims of GSP are found in the source of data. In this case, generosity maxim becomes the most frequent maxim of GSP including all data; It has twenty-two data. The next position provides that agreement maxim is in the second position having twenty data of the total eighty-three data found. Then, approbation maxim has ten data of the total data found. Tact maxim, obligation (of $\mathrm{S}$ to $\mathrm{O}$ ) maxim, and opinion reticence maxim have the same amount of data, each of them has six data. The next position is sympathy maxim having five data of the total eighty-three data found. Obligation (of $\mathrm{O}$ to $\mathrm{S}$ ) maxim and feeling reticence maxim have the same frequent of data, each of them has three data. The lowest frequent maxim of GSP is modesty maxim having two data of the total eighty-three data found.

\section{General Strategy of Politeness Found in MOTHER}

As Leech (2014) wrote, the politeness principles are generosity maxim, tact maxim, approbation maxim, modesty maxim, obligation maxim (of $\mathrm{S}$ to $\mathrm{O}$ ), Obligation maxim (of $\mathrm{O}$ to $\mathrm{S}$ ), agreement maxim, opinion reticence maxim, sympathy maxim, and feeling reticence maxim. Based on the data found, the three maxims that occur frequently are generosity maxim, agreement maxim, and approbation maxim. The discussion focuses on these three maxims. In addition, the writer analyzes each of the data classified into those maxims of GSP based on the definitions proposed by Leech (2014).

\section{Generosity Maxim}

The concept of generosity maxim is to give a high value to other's wants. This maxim can be direct or even impositioning, for example offers, invitations, and promises (Leech, 2014). This maxim has the total twenty-two data analyzed. Extract 1 (taken from Madurese Culture role play script entitled "Marlena") will be the representative of the total twenty-two data that is explained further in the discussion below.

\section{Extract 1 \\ Marlena : Bukan apa-apa, Sit. Aku harus membantu orang tua ku. Kamu tau kan kalau aku anak satu-satunya di keluargaku. \\ Siti $\quad$ : Kamu masih bisa bantu mereka sambil sekolah, kan? Justru karna kamu anak satu-satunya kamu harus buat bangga orang tua mu, Mar! kamu mau selamanya jadi tukang jual sate kayak gini sampek kamu punya anak cucu?}

Both Marlena and Siti insist to give high value to others' wants. Marlena sacrifices herself not to continue her study because her father does not want her to do that. She tries to value her father's want. Moreover, Siti urges Marlena to continue her study at university. She is sure that being well educated is one of the ways to reach a success. Therefore, Marlena and Siti's utterances are classified into generosity maxim.

Marlena and Siti's utterances above sound polite because they contain favorable value to others. The word "harus" becomes insistent direct feature to show that speaker truly supports what others' want. The speakers motivate others/interlocutors to fight for their wants. These can be a good example for the students of college how to imply meaning by avoiding offense in their daily speech event. 


\section{Agreement maxim}

Leech (2014) states that agreement maxim deals with giving value to others' opinions. In responding to others' opinions or judgement, agreement is the preferred response and disagreement is dispreferred response. The following extract about agreement maxim is a representative of the total twenty data.

\section{Extract 2 \\ Siti $\quad$ : Kamu masih bisa bantu mereka sambil sekolah, kan? Justru karna kamu anak satu-satunya kamu harus buat bangga orang tua mu, Mar! kamu mau selamanya jadi tukang jual sate kayak gini sampek kamu punya anak cucu? \\ Marlena : Yaa enggak lah, Sit! Akan aku sekolahkan anak-anak ku nantik sampek dia jadi orang berhasil biar gak kayak aku. \\ Siti : Nah itu kamu bisa berfikir gitu. Dimana Marlena, anak paling pintar dan cerdas di sekolah yang selalu berprestasi dan bersemangat dalam belajar? Ini bukan kamu, Mar. aku tau banget kamu kayak apa orangnya. Jadi, jangan kamu tutupi, Mar.}

From extract 2 above, it can be seen that both Marlena and Siti utter an agreement in responding other's opinion. Marlena agrees with Siti's opinion that she must not be a satay seller in the future. She says "ya enggaklah, Sit!" has the meaning that she agrees about Siti's fear of her future. In addition, Siti says "nah, itu kamu bisa berfikir gitu" to show her agreement when Marlena promises to give best education for her children in the future. They utter preferred responses to respond other's opinion, so these responses are included in agreement maxim.

\section{Approbation Maxim}

This maxim is associated with quality. When speaker gives a high value to others' qualities, it means that she fulfills approbation maxim. As stated by Watt (2003), approbation maxim is to minimize dispraise of other and to maximize praise of other. The speaker tends to give praises to hearers or others. On the other hand, they tend to avoid saying unpleasant things about the others. In the two role play scripts, there are ten data of approbation maxim. The extract contains this maxim will be discussed below.

\section{Extract 3}

Laura :Oh iya, aku ingin bertanya. Kenapa makanan ini diberi nama bebek songkem? Apa ada sejarahnya, Mia?

Mia : Baiklah, aku akan menjelaskannya. Jadi bebek songkem ini memiliki filosofi, sebuah cerita tentang etika, wujud hormat dan terimakasih atau apresiasi para orangtua disini kepada Kyai yang dengan sukarela sudah mengajari anak-anak mengaji. Selain itu, bebek songkem dibawa sebagai hantaran ketika songkeman. Bebek ini bentuknya utuh yang sudah dibentuk seperti orang sungkem dijadikan simbol nilai-nilai sopan santun. 
Laura : Wah (ekspresi kagum), itu sangat keren, Mia. Terlepas dari filosofinya, makanan ini dibentuk untuk menyimbolkan nilainilai sopan santun dimana menurutku jarang sekali makanan dibentuk khusus seperti itu. Aku baru pertama kali menemukan makanan seperti ini. Madura, benar-benar luar biasa (acung jempol).

Laura's bolded utterances above shows that she maximizes praise to Mia's explanation about the origin of bebek songkem. She also tends to give high value to Madura island that has extraordinary food like bebek songkem. It has deep philosophy on its name. Laura does not show any dispraise on her utterance. These utterances are categorized as approbation maxim.

\section{Some Barriers in Utilizing MOTHER}

Seven barriers are encountered during the implementation of MOTHER to accustom students' language politeness. These barriers are found by doing interview and taking field-notes. The barriers are to coordinate and cooperate with the team, to elaborate the plot of the role play, to discover references and find attractive story ideas deal with Madurese themes, to create polite dialogues of the role play, to specifies the context (to whom) the dialogue is addressed to, and to determine the title of role play. They can be seen in Table 2 .

Tabel 2. The barriers Found in Utilizing MOTHER

\begin{tabular}{|l|l|c|}
\hline \multicolumn{1}{|c|}{ No. } & \multicolumn{1}{|c|}{ The barriers } & Percentage \\
\hline 1. & To coordinate and cooperate with the team & 67,7 \\
\hline 2. & To elaborate the plot of the role play & 66 \\
\hline 3. & $\begin{array}{l}\text { To discover references and finding attractive story ideas deal with } \\
\text { Madurese themes }\end{array}$ & 55,9 \\
\hline 4. & To create polite dialogues of the role play & 42,3 \\
\hline 5. & To specifies the context (to whom) the dialogue is addressed to & 32 \\
\hline 6. & To determine the title of role play & 10 \\
\hline
\end{tabular}

Based on the data found, the three barriers that appear mostly are to coordinate and cooperate with the team, to elaborate the plot of the role play, and to discover references and finding attractive story ideas deal with Madurese themes. The discussion focuses on these three barriers.

The most frequent barrier said by respondents are to coordinate and cooperate with the team. As many as $67.7 \%$ of respondents stated that they had difficulty to coordinate with their groups. Based on the data analysis that has been done, this is because the coordination must be done over a long distance or online. The Covid-19 pandemic outbreak, which requires people to communicate long distances is a major factor in the difficulty of coordinating with the team. The determination of tasks and roles in implementing MOTHER must be discussed online, while not all team members have adequate internet facilities so that coordination is not optimal. Following are the statements of several respondents regarding this matter. 
R-2 : “... kesulitan berinteraksi antara anggota kelompok dikarenakan sinyal yangg kurang baik..."

R-5 : “... yang sifatnya online sehingga lambat dalam penyusunan karna interaksi yang sulit..."

R-52 : “... kurangnya komunikasi yang baik antar anggota. Yang sering muncul untuk diskusi di grup, hanya orang itu-itu saja, ya meskipun anggota yang lain juga sudah ikut berdiskusi dan berpartisipatif dengan baik tapi, komunikasi yang lancar juga perlu ditingkatkan agar diskusinya enak, dan nyambung terus."

The second barrier mostly appears is to elaborate the plot of the role play. As many as $66 \%$ of the respondents involved answered "yes" when they are asked if they had difficulty developing the plot of the role play. In this case, language is the main reason. Students have difficulty composing and developing sentences in the script they make. The difficulty in composing and developing these sentences results in him making or arranging an order in the dialogue that is in the role play. Some respondents stated that it was difficult to choose vocabulary mainly in determining the right sentence, compiling a script in good and correct language, and others. Here are some respondents' statements related to the elaborating plot of the role play which is closely related to language.

\section{R-1 : "Kesulitan dalam alur cerita tentang judulnya dan permasalahan yag terjadi..." \\ R-8 : "Kesulitannya mencari tahu cerita yang diangkat, membuat alur dan dialog antar tokoh." \\ R-34 :“...kesulitan membuat kosakata yang bagus dalam merangkai kalimat ... menggabungkan beberapa ide dan pikiran ke dalam suatu teks supaya padu ..."}

The third barrier complained many times is they had difficulty discovering references and finding attractive story ideas deal with Madurese themes. This is because the availability of reference books and articles that specifically discuss some matters related to Madura (such as: folklore, traditions and culture, principles, language, Madurese society, etc.) is still minimal and difficult to find for easy and free access. In this regard, in applying MOTHER, respondents also experienced difficulties in finding story ideas in the role play. As many as 55.9\% of respondents answered 'yes' when asked if they had difficulty finding story ideas in a Madurese theme role play. One of the reasons why they have difficulty in finding story ideas is because many students, especially those from outside Madura, do not understand the traditions that are exist in Madura. So, more references are needed that talk about Madura to find story ideas in the role play. The following is the statements of respondents who experienced difficulties in discovering references and finding story ideas of role play deal with Madurese themes.

$$
\begin{gathered}
\text { R-12 : “... sampai harus mewawancarai tokoh masyarakat yang } \\
\text { mengetahui cerita ...” } \\
\text { R-6 : "Kesulitannya yaitu ..., mencari ide agar cerita menjadi sekreatif } \\
\text { mungkin." }
\end{gathered}
$$




\section{CONCLUSION}

In accordance with what was designed by Leech (2014), the findings in this study have shown that the GSP (General Strategy of Politeness) model has appeared in the utilization of MOTHER (Madurese Theme Role Play) to accustom students to use polite or modest language. The utilization involves the 10 components of maxim, including generosity maxim, tact maxim, approbation maxim, modesty maxim, obligation (of $\mathrm{S}$ to $\mathrm{O}$ ) maxim, Obligation (of $\mathrm{O}$ to $\mathrm{S}$ ) maxim, agreement maxim, opinion reticence maxim, sympathy maxim, and feeling reticence maxim. Moreover, seven barriers are also found during the utilization of MOTHER, including to coordinate and cooperate with the team, to elaborate the plot of the role play, to discover references and find attractive story ideas deal with Madurese themes, to create polite dialogues of the role play, to specifies the context (to whom) the dialogue is addressed to, and to determine the title of role play. Furthermore, the issue of cultural diversity influencing the use of polite language by one speaker and another, for example the values considered norms vary from culture to culture; or being linguistically polite in one culture does not mean polite in another culture. Therefore, it is expected that the next study will explain and discuss further about how cultural values affect the use of the maxims in showing consideration of others' face (public self-image). In this case, an approach that can be particularly used to view the findings or issues related to linguistic politeness is Sociopragmatic scale.

\section{REFERENCES}

Binder, J. (2013). Primary Care Interviewing: Learning Through Role Play. 1st ed. New York: Springer Science+Business Media

Brown, P and Levinson, S. C. (1987). Politeness: Some Universals in Language Usage. 2nd ed. Melbourne: Cambridge University Press.

Kadar, D. Z and Haugh, M. (2013). Understanding Politeness. 1st ed. New York: Cambridge University Press.

Ladousse, G. P. (1987). Role Play. 1st ed. New York: Oxford University Press.

Leech, G. (2014). The Pragmatics of Politeness. 1st ed. New York: Oxford University Press.

Watts, R. J. (2003). Politeness. 1st ed. New York: Cambridge University Press.

Wills et al. (2011). The Power of Role-Based E-Learning: Designing and Moderating Online Role Play. 1st ed. New York: Routledge. 